\title{
Serological detection of Brucella canis in shelter dogs from Northern Paraná
}

\section{Detecção sorológica de Brucella canis em cães de abrigos da região Norte do Paraná}

\author{
Luiz César da Silva ${ }^{1}$; Luis Álvaro Leuzzi Junior ${ }^{1}$; Julyerme Luiz Bagatim Nassar ${ }^{2}$; \\ Flávio Antonio Barca Junior ${ }^{1}$; Selwyn Arlington Headley³; Werner Okano; \\ Bernardo Kemper ${ }^{1}$; Sílvia Manduca Trapp ${ }^{1^{*}}$
}

\begin{abstract}
This study evaluated the presence of circulating antibodies of anti-Brucella canis and anti-B. abortus in shelter dogs maintained in four cities of Northern Paraná. Serum samples of 100 dogs, of both sexes, from the cities of Apucarana, Arapongas, Londrina and Rolândia were collected for the determination of the serological presence of B. canis by the utilization of agarose gel immunodiffusion and B. abortus by the buffered acidified antigen assay. Only 4\% (4/100) of the samples evaluated demonstrated seroreactivity to $B$. canis, with seropositivity varying between $4.17-10 \%$. However, positive samples originated only from the cities of Apucarana $(4.17 \% ; 2 / 48)$ and Londrina $(10 \% ; 2 / 20)$. Seroreactivity to $B$. abortus antibodies was not verified within the canine population evaluated. These results suggest that B. canis is circulating within the dog population of Northern Paraná.
\end{abstract}

Key words: Canine disease, epidemiology, brucellosis, serology

\section{Resumo}

Este estudo avaliou a presença de anticorpos circulantes anti-Brucella canis e anti-B. abortus em cães mantidos em abrigos situados em quatro municípios da região Norte do Paraná. Amostras séricas de 100 cães, de ambos os sexos, oriundos das cidades de Apucarana, Arapongas, Londrina e Rolândia foram colhidas para determinação sorológica da presença de anticorpos contra $B$. canis por meio da técnica de imunodifusão em gel de agarose e de anticorpos contra $B$. abortus por meio da prova do antígeno acidificado tamponado. Somente $4 \%(4 / 100)$ das amostras avaliadas foram sororreagentes a $B$. canis, com soropositividade variando entre $4.17-10 \%$. Contudo, as amostras positivas foram oriundas somente das cidades de Apucarana $(4.17 \% ; 2 / 48)$ e Londrina $(10 \% ; 2 / 20)$. Não foram verificadas amostras sororreagentes a $B$. abortus na população canina avaliada. Esses resultados sugerem que $B$. Canis circula na população de cães da região Norte do Paraná.

Palavras-chave: Doença canina; epidemiologia; brucelose; sorologia

\footnotetext{
${ }^{1}$ Profs. de Graduação em Medicina Veterinária da Universidade Norte do Paraná, UNOPAR, Arapongas, PR. E-mail: silvaluizcesar@, hotmail.com; luis.leuzzi@unopar.br; flavio.barca@gmail.com; bernardo_kemper@hotmail.com; smanducatrapp@gmail.com

${ }^{2}$ Médico Veterinário autônomo, Londrina, PR. E-mail: jlbnassar@hotmail.com

${ }^{3}$ Profs. do Mestrado em Saúde e Produção de Ruminantes e de Graduação em Medicina Veterinária da UNOPAR, Arapongas, PR. E-mail: headleysa@gmail.com; vetwerner@gmail.com

* Author for corespondence
} 
Canine brucellosis (CB) is a reproductive disease that is caused by Brucella canis and is characterized by abortion, orchitis, epididymitis, and testicular atrophy. However, cases of asymptomatic or systemic brucellosis have been described (GREENE; CARMICHAEL, 2006). Dogs might also demonstrate sensitivity to infection by $B$. abortus, particularly those in rural areas that are in contact with potentially infected species such as cattle (FORBES, 1990).

Due to the difficulties and the convenience associated with the clinical diagnosis of $\mathrm{CB}$, serology is the most frequently technique for the diagnosis of infection induced by B. canis in dogs. Nevertheless, the agarose gel immunodiffusion (AGID) assay is the most frequently used method (FERREIRA et al., 2007; GREENE; CARMICHAEL, 2006). The cross-reactivity of antigens between $B$. canis and $B$. ovis enables the indistinct use of reactions produced from these two microorganisms for the diagnosis of brucellosis in sheep and dogs.

Considering the complex relationship existing between the canine population and humans and due to the antropozoonotic characteristics of $\mathrm{CB}$, the implications of $B$. canis on public health cannot be underscored (GREENE; CARMICHAEL, 2006). Changes in family structure over the recent decades have led to an increase in the number of person living only with pets; the consequent close relationship between humans and dogs enhances the risk of transmitting diseases or infections (BAHR; MORAIS, 2001).

The occurrence of $\mathrm{CB}$ in Brazil varies between $0.84 \%$ in Botucatu, São Paulo (MORAES et al., 2002) and 72.7\% Uruguaiana, Rio Grande do Sul (VARGAS et al., 1996). Further, most studies of $\mathrm{CB}$ were done within the states of the Southeastern region of Brazil (ALMEIDA et al., 2004; AZEVEDO et al., 2004; FERREIRA et al., 2007), with few epidemiological surveys realized in northern (AGUIAR et al., 2005), and north-eastern (CAVALCANTI et al., 2006; PORTO; PINHEIRO JUNIOR; MOTA, 2008) Brazil. There is one epidemiological survey ofCB within southern Brazil
(VARGAS et al., 1996). However, no description of the incidence of CB within the state of Paraná was obtained when major data bases were consulted. Further, knowledge relative to the occurrence of B. canis is fundamental for the implementation of control strategies and prophylactic measures to prevent the introduction of the agent into geographical regions that are free of this pathogen (PORTO; PINHEIRO JUNIOR; MOTA, 2008). Consequently, the objective of this study was to determine the possible occurrence of anti-B. canis and anti-B. abortus antibodies in dogs maintained in animal shelters within northern Paraná.

Serological samples of 100 stray dogs maintained in animal shelters located within the cities of Apucarana, Arapongas, Rolândia, and Londrina were used during this study. These dogs were of different breeds, of both sexes, and were more than one year of age; however, most dogs were mongrels. Information relative to the clinical manifestations of disease was not collected.

Blood samples were obtained aseptically by cephalic venipuncture and transferred to sterile tubes without anticoagulant. The diagnosis of Brucella canis was done by using the agarose gel immunodiffusion (AGID) technique, standardized with lipopolysaccharide and protein antigens of $B$. ovis (sample Reo 198), produced by the Instituto de Tecnologia do Paraná (TECPAR). The test was done as indicated by laboratory recommendations (TECPAR) with the utilization of $1 \%$ agar Nobel gel (Difco, Detroit, MI, USA). The identification of anti- $B$. abortus antibodies was done by using the Buffered Acidified Antigen test in Klein plates to which $30 \mu \mathrm{l}$ of canine sera was added to an equal volume of antigen of $B$. abortus (rose Bengal). All laboratory procedures were done at the Center for Veterinary Diagnosis, Universidade Norte do Paraná, Arapongas, PR.

The Fischer test was used to determine possible sexual predominance relative to the occurrence of canine brucellosis using a significance level of $0.05 \%$. 
Only 4\% (4/100) of the samples that were analysed by AGID demonstrated positive reactivity to anti-Brucella canis antibodies. However, four of the negative samples revealed precipitation lines that were different from the standard serum and were interpreted as nonspecific reactions (Table 1). Nonspecific reactions are known to occur when lipopolysaccharide antigens are used with the AGID technique; however, the line created by the precipitated serum is different from that observed in sera diagnosed as false-positive (GREENE; CARMICHAEL, 2006). Most dogs (92\%; 92/100) irrespective of the city of origin, demonstrated negative seroreactivity to $B$. canis. Further, dogs with positive seroreactivity to $B$. canis originated from Apucarana $(4.17 \% ; 2 / 48)$ and Londrina $(10 \%$; 2/20); shelter dogs from the cities of Arapongas and Rolândia did not demonstrate seroreactivity to $B$. canis (Table 1).

Table 1. The seroreactivity of shelter dogs to Brucella canis within cities of Northern Paraná.

\begin{tabular}{|c|c|c|c|c|c|c|c|}
\hline \multirow{3}{*}{ Cities } & \multicolumn{6}{|c|}{ Seroreactivity by sex } & \multirow{3}{*}{$\begin{array}{l}\text { Total number of dogs } \\
\quad \text { (prevalence; \%) }\end{array}$} \\
\hline & \multicolumn{2}{|c|}{ Positive } & \multicolumn{2}{|c|}{ Unspecific } & \multicolumn{2}{|c|}{ Negative } & \\
\hline & $\mathrm{M}$ & $\mathrm{F}$ & $\mathrm{M}$ & $\mathrm{F}$ & $\mathrm{M}$ & $\mathrm{F}$ & \\
\hline Apucarana & 1 & 1 & 2 & 2 & 19 & 23 & $48(4.17)$ \\
\hline Arapongas & 0 & 0 & 0 & 0 & 4 & 15 & $19(0)$ \\
\hline Londrina & 1 & 1 & 0 & 0 & 5 & 13 & $20(10)$ \\
\hline Rolândia & 0 & 0 & 0 & 0 & 7 & 6 & $13(0)$ \\
\hline Total & 2 & 2 & 2 & 2 & 35 & 57 & $100(4)$ \\
\hline
\end{tabular}

M, male; F, female.

Source: Elaboration of the authors.

The average seroprevalence $(4 \%)$ of $B$. canis observed during this study by AGID is similar to other reports realized in different geographical regions of Brazil: Rio de Janeiro, RJ, 2.53\% (CAVALCANTI et al., 2006); Monte Negro, RO, 3.6\% (AGUIAR et al., 2005); Maceió, AL, 4.4\% (PORTO; PINHEIRO JUNIOR; MOTA, 2008); and Salvador, BA, 5.88\% (FERREIRA et al., 2007). Alternatively, more elevated prevalence levels were described in Santana de Parnaíba, SP, 9.51\% (AZEVEDO et al., 2004); Alfenas, MG, 14.2\% (ALMEIDA et al., 2004); and Uruguaiana, RS, 72.7\% (VARGAS et al., 1966). These differences in infections levels can be associated with the laboratory technique used, the type of animal (household, stray, or shelter dogs) evaluated (ALMEIDA et al., 2004), the geographical location, and even the phase of infection (GREENE; CARMICHAEL, 2006). Studies have suggested that dogs at the onset of infection might be serumnegative by AGID (GREENE; CARMICHAEL,
2006), with confirmation of positive serum reactivity occurring only effective from the $5^{\text {th }}-10^{\text {th }}$ week of infection (GREENE; CARMICHAEL, 2006).

When serology (AGID, rapid agglutination test with and without 2-mercaptoethanol), microbiological culture, and polymerase chain reaction (PCR) were compared for the efficient diagnosis of B. canis (KEID et al., 2009), it was demonstrated that a significant proportion of serological evaluations yielded false-negative results. These authors also indicated the importance of direct evaluations (PCR and/or bacteriological culture) to improve the efficiency of the diagnosis of $\mathrm{CB}$; the absence and/or non-utilization of these might techniques be partially responsible for the reduced prevalence indices described in this and other studies.

The utilization of PCR has facilitated the direct diagnosis of infectious agents, thereby dispensing 
microbiological culture. It also allows for the diagnosis of disease pathogens even during phases of infections where the amount of circulating bacteria might be relatively small, thereby making bacterial isolation difficult. Further, PCR is not dependent on the viability of the infectious agent. Nevertheless, the sensitivity and/or specificity of PCR for the diagnosis of $B$. canis might be affected by the type of sample. Studies have demonstrated that in dogs with reproductive problems or naturally infected by $B$ canis, the identification of this pathogen by PCR using vaginal swabs or semen samples is more sensitive comparable to the utilization of PCR derived from blood or serum samples (KEID et al., 2007). Additionally, the utilization of serum samples of infected dogs for the diagnosis of $B$ canis by PCR is of restricted diagnostic value (KEID et al., 2010).

No dog demonstrated seroreactivity to antiBrucella abortus antibodies by the Buffered Acidified Antigen (BAA) test. The absence (PORTO; PINHEIRO JUNIOR; MOTA, 2008) or low seroreactivity $(0.3 \%$ to $2.91 \%)$ of dogs to $B$. abortus has also been detected in other studies (AGUIAR et al., 2005).

Infection by $B$. abortus in dogs is sporadic and associated with the ingestion of contaminated foods of animal origin and the remnants of aborted bovine material (GREENE; CARMICHAEL, 2006; FORBES, 1990). Since most of the dogs evaluated during this study were mongrels maintained in shelters it was not possible to determine their original residence, i.e., if they were originated from rural areas and hence more apt to be in contact with contaminated animal remnants or animals infected by brucellosis. Additionally, a seroepidemiological survey of bovine brucellosis within the state of Paraná has demonstrated that prevalence indices varies between $0.85 \%$ to $2.82 \%$, with $2.4 \%$ of cattle from the Centre/West/Northern of Paraná being seropositive (DIAS et al., 2009); this reduced prevalence of bovine brucellosis within our region might have also contributed to the negative results observed during this study.
Shelter dogs were targeted during this study because of their roaming habit, which makes this specific canine population more susceptible to infectious diseases (NAKAGAWA et al., 2007). It can then be inferred that the reduced seroreactivity observed during this study coupled with the low prevalence of bovine brucellosis within the state of Paraná might suggest that the incidence of brucellosis in some species of domestic animals is relatively low. However, additional seroepidemiological surveys of the impacts of brucellosis on domestic animals within the state of Paraná are warranted to confirm this theory.

During this study significant statistical differences were not observed when the sex of the dog infected was compared (Table 1); similar results have been described (MORAES et al., 2002; ALMEIDA et al., 2004; CAVALCANTI et al., 2006; PORTO; PINHEIRO JUNIOR; MOTA, 2008). These results might suggest that sexual preference is not an important epidemiological factor associated with the transmission of CB.

The findings of this study suggest that these dogs within northern Paraná serve as reservoirs for $B$. canis. Due to the risk of contamination of susceptible canine, mammalian, and human populations, and considering that brucellosis is characterized as an anthropozoonosis, control and prophylactic measures are necessary, and should be implemented to prevent the dissemination of B. canis. Further, the results of this study might represent the first seroepidemiological evidence of canine brucellosis in the state of Paraná.

\section{References}

AGUIAR, D. M.; CAVALCANTE, G. T.; VASCONCELLOS, S. A.; MEGID, J.; SALGADO, V. R.; CRUZ, T. F.; LABRUNA, M. B.; PINTER, A.; SILVA, J. C. R.; MORAES, Z. M.; CAMARGO, L. M. A.; GENNARI, S. M. Ocorrência de anticorpos antiBrucella abortus e anti-Brucella canis em cães rurais e urbanos do Município de Monte Negro, Rondônia, Brasil. Ciência Rural, Santa Maria, v. 35, n. 5, p. 12161219, 2005. 
ALMEIDA, A. C.; SANTORELLI, A.; BRUZADELLI, R. M. Z.; OLIVEIRA, M. M. N. F. Soroepidemiologia da brucelose canina causada por Brucella canis e Brucella abortus na cidade de Alfenas, MG. Arquivo Brasileiro de Medicina Veterinária e Zootecnia, Belo Horizonte, v. 56, n. 2, p. 275-276, 2004.

AZEVEDO, S. S.; VASCONCELLOS, S.A.; KEID, L. B.; GRASSO, L. M. P. S.; PINHEIRO, S. R.; MASCOLLI, R.; ALVES, C. J. Comparação de três testes sorológicos aplicados ao diagnóstico da infecção de caninos por Brucella canis. Brazilian Journal of Veterinary and Animal Science, São Paulo, v. 41, n. 2, p. 106-112, 2004.

BAHR, S. E.; MORAIS, H. A. Pessoas imunocomprometidas e animais de estimação. Revista Clínica Veterinária, São Paulo, n. 30, p. 17-22, 2001.

CAVALCANTI, L. A.; DASSO, M. G.; OLIVEIRA, F. C. S.; VIEGAS, S. A. R. A.; ALMEIDA, M. G. A. R.; ANUNCIAÇÃO, A. V. M.; ALCANTARA, A. C.; BITTENCOURT, D. V. V.; OLIVEIRA, E. M. D. Pesquisa de anticorpos anti-Brucella canis em cães provenientes da região metropolitana de Salvador. Revista Brasileira de Saúde e Produção Animal, Salvador, v. 7, n. 2, p. 176180, 2006.

DIAS, J. A.; MÜLLER, E. E.; DIAS, R. A.; FREITAS, J. C.; AMAKU, M.; FERREIRA, F.; SILVA, M. C. P.; LÔBO, J. R.; FIGUEIREDO, V. C. R.; GONÇALVES, V. S. P.; FERREIRA NETO, J. S. Situação epidemiológica da brucelose bovina no Estado do Paraná. Arquivo Brasileiro de Medicina Veterinária e Zootecnia, Belo Horizonte, v. 61, p. 66-76, 2009. Suplemento 1.

FERREIRA, T.; MANDELBAUM, M. A.; MARQUES, A. P. L.; TORRES, H. M.; FIGUEIREDO, M. J.; SERRA, C. M.; AQUINO, M. H. C. Inquérito sorológico da brucelose canina através da utilização de antígeno externo e interno de Brucella canis e Brucella ovis. Revista Brasileira de Ciência Veterinária, Rio de Janeiro, v. 14, n. 3, p. 167-168, 2007.

FORBES, L. B. B. abortus infection in 14 farm dogs. Journal of the American Veterinary Medical Association, Schaumburg, v. 196, n. 6, p. 911-916, 1990.

GREENE, C. E.; CARMICHAEL, L. E. Canine brucellosis. In: GREENE, C. E. Infectious diseases. 3. ed. St. Louis: Saunders Elsevier, 2006. p. 369-381.
KEID, L. B.; SOARES, R. M.; VASCONCELLOS, S. A.; CHIEBAO, D. P.; MEGID, J.; SALGADO, V. R.; RICHTZENHAIN, L. J. A polymerase chain reaction for the detection of Brucella canis in semen of naturally infected dogs. Theriogenology, Stoneham, v. 67, n. 7, p. 1203-1210, 2007.

KEID, L. B.; SOARES, R. M.; VASCONCELLOS, S. A.; MEGID, J.; SALGADO, V. R.; RICHTZENHAIN, L. J. Comparison of Agar gel immunodiffusion test, rapid slide agglutination test, microbiological culture and PCR for the diagnosis of canine brucellosis. Research in Veterinary Science, London, v. 86, n. 1, p. 22-26, 2009.

KEID, L. B.; SOARES, R. M.; VASCONCELLOS, S. A.; SALGADO, V. R.; MEGID, J.; RICHTZENHAIN, L. J. Comparison of a PCR assay in whole blood and serum specimens for canine brucellosis diagnosis. Veterinary Record, London, v. 167, n. 3, p. 96-99, 2010.

MORAES, C. C. G.; MEGID, J.; SOUZA, L. C.; CROCCI, A. J. Prevalência da brucelose canina na microrregião da serra de Botucatu, São Paulo, Brasil. Arquivos do Instituto Biológico, São Paulo, v. 69, n. 2, p. 7-10, 2002.

NAKAGAWA, T. L. D. R.; BRACARENCE, A. P. F. R. L.; REIS, A. C. F.; YAMAMURA, M. H.; HEADLEY, S. A. Giant kidney worm (Dioctophyma renale) infections in dogs from Northern Paraná, Brazil. Veterinary Parasitology, Amsterdam, v. 145 , n. 3-4, p. 366-370, 2007.

PORTO, W. J. N.; PINHEIRO JUNIOR, J. W.; MOTA, R. A. Associação entre distúrbios reprodutivos e anticorpos anti-Brucella sp em cães atendidos em clínicas particulares da cidade de Maceió-AL. Revista Brasileira de Ciência Veterinária, Rio de Janeiro, v. 15, n. 1, p. 6-9, 2008.

VARGAS, A. C.; LAZZARI, A.; DUTRA, V.; POESTER, P. Brucelose canina: relato de caso. Ciência Rural, Santa Maria, v. 26, n. 2, p. 305-308, 1996. 
